\title{
Molecular Detection and Characterization of Papaya Ring Spot Virus (PRSV) Disease in Jorhat District of Assam, India
}

\author{
Shankar Hemanta Gogoi ${ }^{1 *}$, P.D. Nath ${ }^{1}$, N. Thakuria ${ }^{2}$, S. Gogoi ${ }^{2}$, \\ B. Das ${ }^{2}$, N. Deka ${ }^{3}$ and K. Raj ${ }^{3}$ \\ ${ }^{1}$ Department of Plant Pathology, College of Agriculture, Assam Agricultural University, \\ Jorhat-13, Assam, India \\ ${ }^{2}$ Institute of Science and Technology, Guwahati University, Guwahati-781014, Assam, India \\ ${ }^{3}$ Sikkim Manipal Institute of Medical Sciences, Sikkim-737102, India \\ *Corresponding author
}

\section{A B S T R A C T}

\section{Keywords}

Papaya ring spot virus (PRSV),

Symptoms, PCR,

NCBI, Phylogeny

Article Info

Accepted:

12 January 2019

Available Online:

10 February 2019
Papaya ring spot virus (PRSV) is the most destructive disease of Papaya, responsible for yield reduction of Papaya all over the world. PRSV exhibited different types of symptoms on Papaya plant in the field like ringspot, vein clearing, vein banding, chlorosis of younger leaves, filiformy, shoestring, mosaic, mottling, stunted growth etc. Molecular diagnosis of PRSV was done with the help of gene specific primers through PCR. Gel electrophoresis results show a 300bp clear band which confirms the presence of PRSV in the plants. Sequencing was done and phylogenetic tree was made. Sequencing results showed 89-97 percent identities with other PRSV isolates present in NCBI Genebank. Phylogenetic analysis reveals that the PRSV Jorhat isolate is closely similar to that Assam isolate Accession no. KC149500.

\section{Introduction}

Papaya (Carica papaya L.) is one of the important tropical and subtropical fruit crops growing throughout India. It is grown as vegetables, table fruits, soups, sauces and jams. The fruit is highly nutritious as it contains higher amount of antioxidants such as carotenes, vitamins and trace elements. Roots are used to cure piles and yaws which act as generative toxin. The area and production of Papaya is about 39.3 thousand hectares and 1.5 million tone ripe fruit per year which stand second highest position in the World after Brazil. For production of papaya, relatively low maintenance costs with lesser amount of pesticides are required as compared to most other tropical fruits and within the first year of planting commercial production is possible (Davis and Ying, 1999).

Papaya is infected by a number of viruses belonging to Begomo- [Papaya leaf curl virus (Saxena et al., 1998); Squash yellow mottle virus (Karkashian et al., 2002); Pepper 
hausteco virus (Garzon-Tiznado et al., 2002); Pepper texas virus (Garzon-Tiznado et al., 2002)], Poty- (Papaya ringspot virus (Purcifull et al., 1984), Zucchini yellow mosaic virus (Ferwerde-Licha, 2002); Soybean yellow bud virus (Rezende and Costa, 1986); Papaya leaf distortion mosaic virus (Kawano and Yonaha, 1992)], Ilar[Tobacco streak virus (Rezende and Costa, 1987)], Nepo- [Tobacco ringspot virus (McLean and Olson, 1962)], Cucumo[Cucumber mosaic virus (Rezende and Costa, 1987)], Potex- [Papaya mosaic virus (Purcifull and Hiebert, 1971)]. The virus seems to be widespread and occurs wherever papaya is grown. The viruses are transmitted through several aphid vectors and also by sap (Wang, 1981; Hwang and Hsieh, 1984; Purcifull et al., 1984; Mali, 1985).

Papaya Ring Spot Virus (PRSV) disease synonymous to papaya mosaic or watermelon mosaic virus- 1 disease is the most widespread and devastating that infects papaya throughout India. Its incidence ranges from 80 to 100 per cent in susceptible cultivars depending on the season and has threatened commercial cultivation and papaya based industries in North East as well as India. PRSV was first described in 1945 and Jensen (1949) first coined the term PRSV. PRSV belongs to the species Papaya Ring Spot Virus, Genus potyvirus of the family potyviridae. It is a positive sense single stranded RNA virus with 9000 to 10,326 nucleotides in length excluding the poly ' $\mathrm{A}$ ' tail (Wang And Yeh, 1997). The flexuous filamentus rod PSRV particle typically measuring 760-800 nm x $12 \mathrm{~nm}$ in dimension (Yeh and Gonsalves, 1985), encapsidated by $30-36 \mathrm{kD}$ coat protein. Two major pathotypes of PSRV are being found i.e type $\mathrm{P}$ (pathogenic to both papaya and cucurbits) and type W [(previously designated as Watermelon Mosaic Virus -I) pathogenic to cucurbits].
The name of the disease Papaya mosaic (In India) is based on symptoms in the host and its transmission that's why it is quite confusing and misleading. Due to the existence of different strains proper diagnosis of PRSV is very important. Through many times PRSV suspected symptoms have been observed in Assam but not much attempt has been made to record the PRSV at molecular level. Therefore, the present investigation was undertaken to carry out a systematic study on the molecular characterization of PRSV in Assam.

\section{Materials and Methods}

\section{Collection and maintenance of diseased plant samples}

Papaya ring spot virus (PRSV) infected plant leaves showing characteristic symptom of the disease in the field were taken carefully in sample collection bag and brought to the laboratory. Molecular detection of the collected samples was done for confirmation of the Papaya ring spot virus (PRSV) infection. Some of the plant samples were also stored in the deep freezer at $-45^{\circ} \mathrm{C}$ for further studies.

\section{Symptomatology of Papaya Ring Spot Virus (PRSV) disease}

The Papaya ring spot virus (PRSV) infected plants in various locations were observed carefully and different types of symptoms developed in the infected plants were recorded.

\section{RNA isolation using TRIzol method}

Total RNA was isolated from papaya leaf samples using standard Tri-Reagent method as described by Akad and Czosnek (2002) with slight modifications. Tri-Reagent method or commonly known as TRIzol method was 
carried out using RNAiso plus reagent from Takara Clonetech containing 38 per cent phenol. Trizol is a mixture of guanidine thioacyanate and phenol, which effectively dissolves DNA, RNA and protein on homogenization or lysis of tissue sample. The samples were ground with liquid nitrogen using mortar and pestle. After grinding the samples to a fine powder, the powdered samples were transferred to a sterile microfuge tube $(2 \mathrm{ml})$ and $1 \mathrm{ml}$ RNAiso reagent was added to it. Then, $200 \mu \mathrm{l}$ of chloroform was added to it and vortexed vigorously and then it was incubated in ice for 15 minutes. After that, the contents of the microfuge tube were subjected to centrifugation at $12000 \mathrm{rpm}$ for 15 minutes at $4^{\circ} \mathrm{C}$. After adding chloroform and centrifuging, the mixture separates into 3 phases with the upper clear aqueous phase containing the RNA. The upper aqueous phase was transferred to a new tube and RNA was precipitated in it by adding $500 \mu \mathrm{l}$ of isopropanol and mixing it by pipetting. Again, the tubes were incubated in ice for 10 minutes. After incubation in ice, the tubes were subjected to centrifugation at $12000 \mathrm{rpm}$ for 10 minutes at $4^{\circ} \mathrm{C}$. After this step, the supernatant from the tube was removed and the pellet was washed with $1 \mathrm{ml} 70$ per cent ice cold ethanol by flicking. After washing, the pellet was centrifuged at $7500 \mathrm{rpm}$ for 10 minutes at $4^{\circ} \mathrm{C}$. Lastly, the supernatant obtained was removed and the pellet was allowed to air dry for some time. After air drying the pellet, it was dissolved in appropriate amount of RNase free sterile distilled water and made into aliquots and stored at $-45^{\circ} \mathrm{C}$ for future use.

\section{Reverse transcription}

Total RNA from healthy and PRSV infected papaya samples were used for reverse transcription. A $20 \mu \mathrm{L}$ reverse transcription (RT) mixture was prepared by following the protocol of TaKaRaPrimeScript reverse transcription kit. $1 \mu \mathrm{L}$ of viral RNA was used in these reactions while sterile water was used in no template control. The RT mixture was reverse transcribed at $50{ }^{\circ} \mathrm{C}$ for 30 minutes and then at $70{ }^{\circ} \mathrm{C}$ for 15 minutes (Cool it in ice). The cDNA thus obtained was used for performing further PCR reactions.

\section{PCR amplification of coat protein genes}

The cDNA thus obtained was subjected to PCR amplification using 5' AGAAGC GTGGGTCAATGGA 3' and 5' CTCTCC AG TTTTTGTGCTAGTTG 3' as forward primer and reverse primers respectively. The reactions were carried out in an Eppendorf thermo-cycler in $10.0 \mu \mathrm{L}$ reaction volume. A typical PCR reaction contained $0.5 \mu \mathrm{L}$ of Prime script 1step, $6.25 \mu \mathrm{L}$ of $2 \mathrm{X}$ 1step buffer, $1.0 \mu \mathrm{L}$ of cDNA, $0.5 \mu \mathrm{L}$ each of forward and reverse primer and the total volume was adjusted to $10 \mu \mathrm{L}$ with DEPC treated sterile water.

The mixture was subjected to one cycle of initial denaturation at $95{ }^{\circ} \mathrm{C}$ for 2 minutes followed by 30 cycles of denaturation at 95 ${ }^{\circ} \mathrm{C}$ for 30 seconds, annealing at primer specific temperature for 1 minute, extension at $72{ }^{\circ} \mathrm{C}$ for 1 minute and 30 seconds and a final extension at $72{ }^{\circ} \mathrm{C}$ for 5 minutes. After completion of the $\mathrm{PCR}$ reaction all PCR amplicons were resolved on $1.5 \%$ agarose gel in $1 \mathrm{X} \mathrm{TBE}$, stained with $0.06 \mu \mathrm{l} / \mathrm{ml}$ ethidium bromide and visualized under UV light in Gel documentation system (BIO RAD).

\section{Sequencing of amplified PCR product}

The amplified PCR product was send to Bioserve Biotechnologies India Pvt. Ltd. Hyderabad, India for sequencing. Sequencing was done in both directions using forward and reverse primers. 


\section{Construction of phylogenetic tree}

The sequence homology was analysed using BLAST (www.ncbi.nih.gov /BLAST).

The Neighbour joining phylogenetic tree was generated using MEGA 7 software tool. To calculate the confidence limits placed in construction of phylogenetic tree, bootstrapping analysis was carried out using 1000 replicates resulting in a boot strapped Neighbour joining tree.

\section{Results and Discussion}

\section{Symptomatology}

The Papaya ring spot disease exhibited different types of symptoms on papaya plants. Symptoms varied from chlorotic mottling of the leaves to severe rugosity.

Infected plants showed stunted growth, chlorosis on the youngest leaves, mosaic, vein clearing, vein banding and mottling of leaf lamina.

In the severe cause's filiformy and shoestring were found on the leaf tendrils. Elongated dark green streaks were observed on petioles and upper half of the stem symptoms of blistering (Fig. 1).

Various types of symptoms produced by PRSV like ringspot on fruits, leaves and stems; mild to severe mosaic, mottling, shoestring leaf, filiform leaf, vein clearing, vein curling, distortion of fruits, leaves and stems; puckering, leaf rolling, leaf curling, vein zigzag, fruit yellowing and stunting growth of plants were described by many scientists (Khurana and Bhargava, 1970; Surekha et al., 1978; Verma and Prasad, 1986; Verma, 1996; Marys et al., 2000; Singh, 2003; Jain et al., 2004).

\section{Molecular characterization of Coat Protein (CP) genes of PRSV isolates}

\section{PCR amplification}

The infected leaf samples of papaya expressing symptoms typical of PRSV infection were confirmed by PCR analysis. Total RNA was isolated from the leaf samples that were flash frozen in liquid Nitrogen and the cDNA was synthesized by using reverse transcription. The primer pair 5' AGAAGCGTGGGTCAATGGA $3^{\prime}$ and $5^{\prime}$ CTCTCCAGTTTTTGTGCTAGTTG 3' were used as the forward and the reverse primers for amplifying part of the coat protein gene. The size of amplified product (300 base pairs) was confirmed on an agarose gel (Fig. 2).

\section{Sequencing of coat protein gene}

The amplified PCR product was send to Bioserve Biotechnologies India Pvt. Ltd. Hyderabad, India for sequencing. Sequencing was done in both directions using forward and reverse primers. A contig was made by using both forward and reverse sequence in Codon Code Aligner. Blast analysis of the sequence shows 87-96 per cent sequence identity with other PRSV isolate present in the National Center for Biotechnology Information (NCBI) Genebank. PRSV Jorhat isolate showed highest nucleotide identity of 96 per cent with $\mathrm{CP}$ gene sequences of accession KC149500 (Assam isolate) followed by 95 per cent with MF356497 (Meghalaya isolate) and 87 per cent with X025002 (Pakistan isolate).

\section{Phylogenetic analysis}

Phylogenetic tree was constructed based on the nucleotide sequences of the Coat protein gene from present investigation and sequences of fifty other PRSV isolates available in the NCBI Genebank. 
Fig.1 Various symptoms of Papaya Ring Spot Virus (PRSV) on papaya

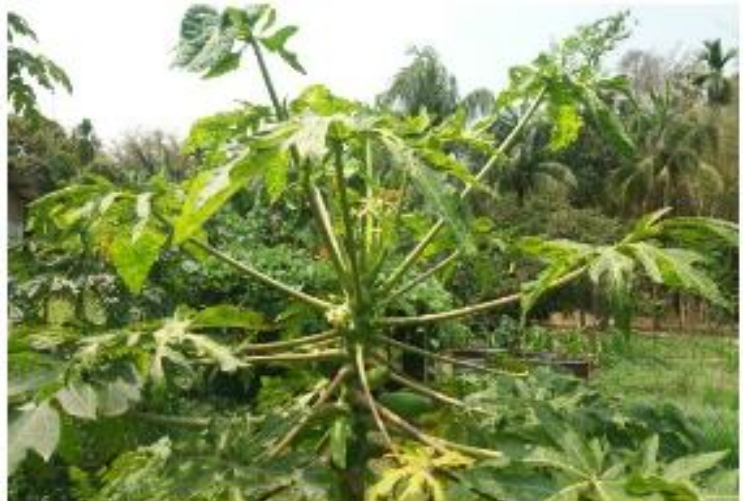

Yellow mosaic and mottling

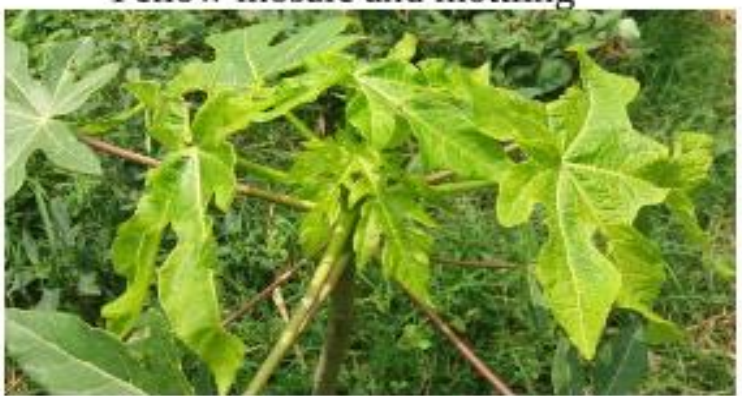

Chlorosis of the leaves

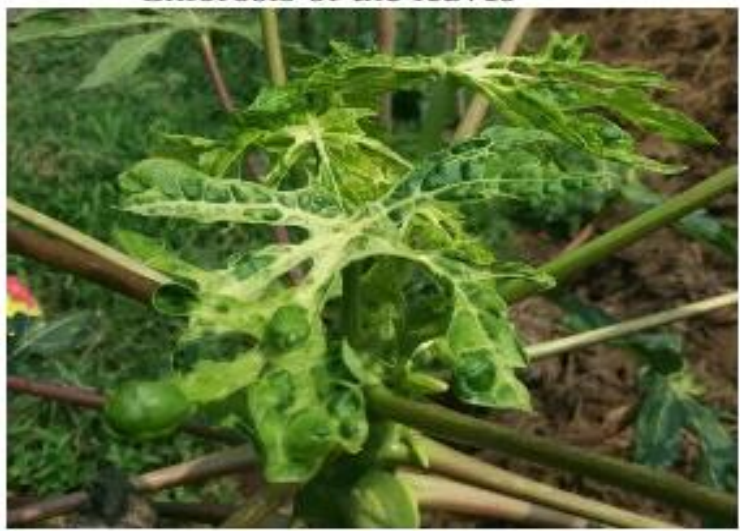

Malformation, filiformy and blistering



Vein clearing

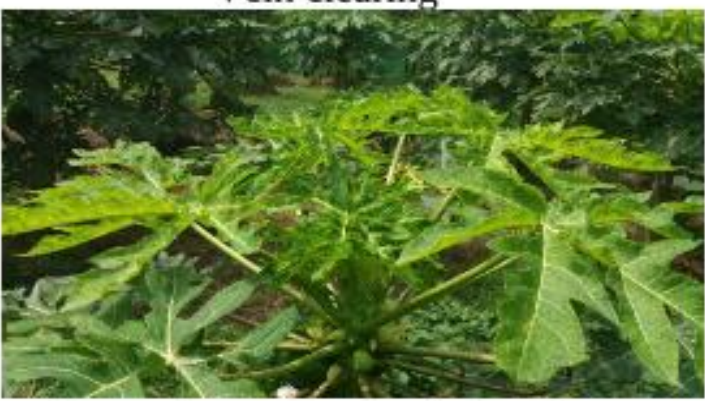

Stunted growth and vein banding

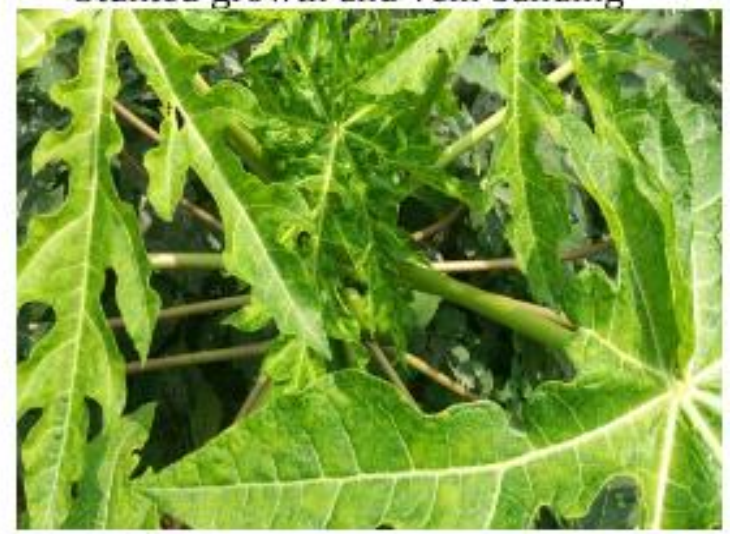

Mosaic

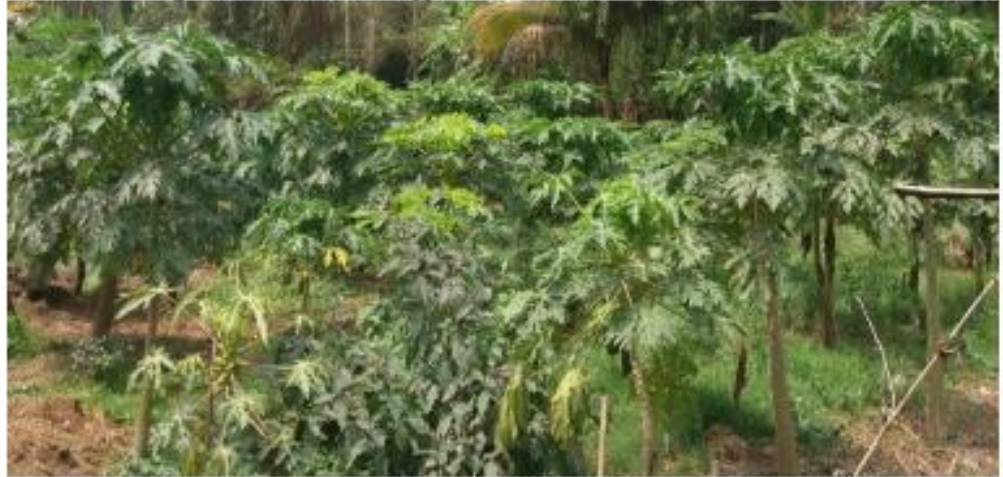

General view of the PRSV infected field 
Fig.2 Gel electrophoresis photograph of PCR amplified product, M. 100 bp DNA Ladder; 1Healthy Papaya Plant; 2-3. Symptomatic Papaya Plants

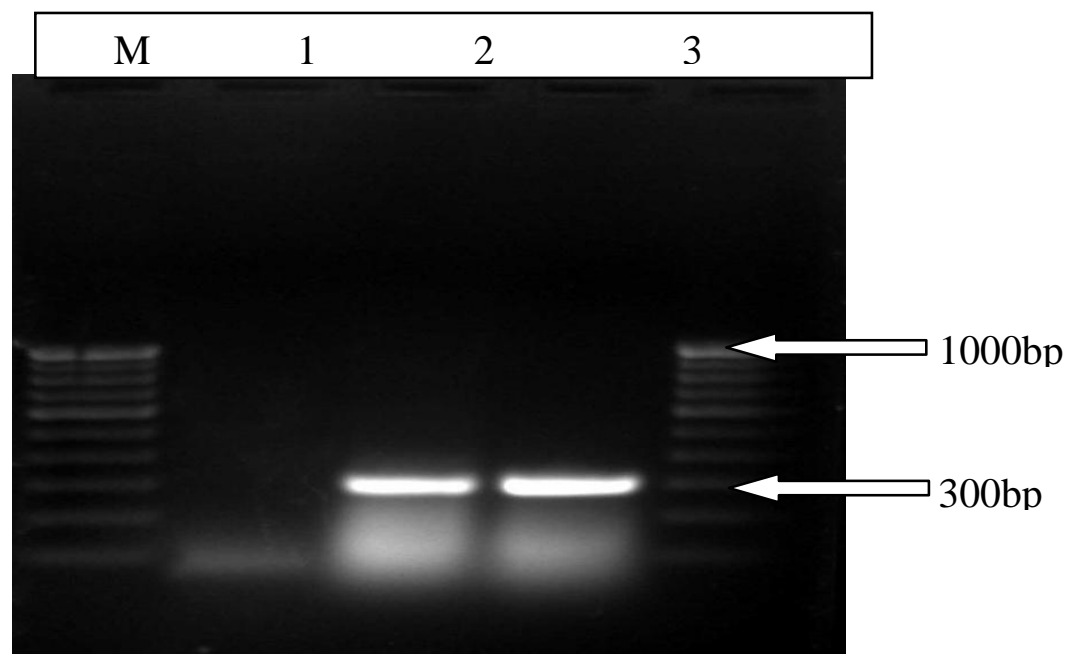

Fig.3 Phylogenetic tree created based on the nucleotide sequences of the coat protein gene of different PRSV isolates: bootstrapped Neighbour Joining method using the software MEGA 6 was used to create the phylogenetic tree

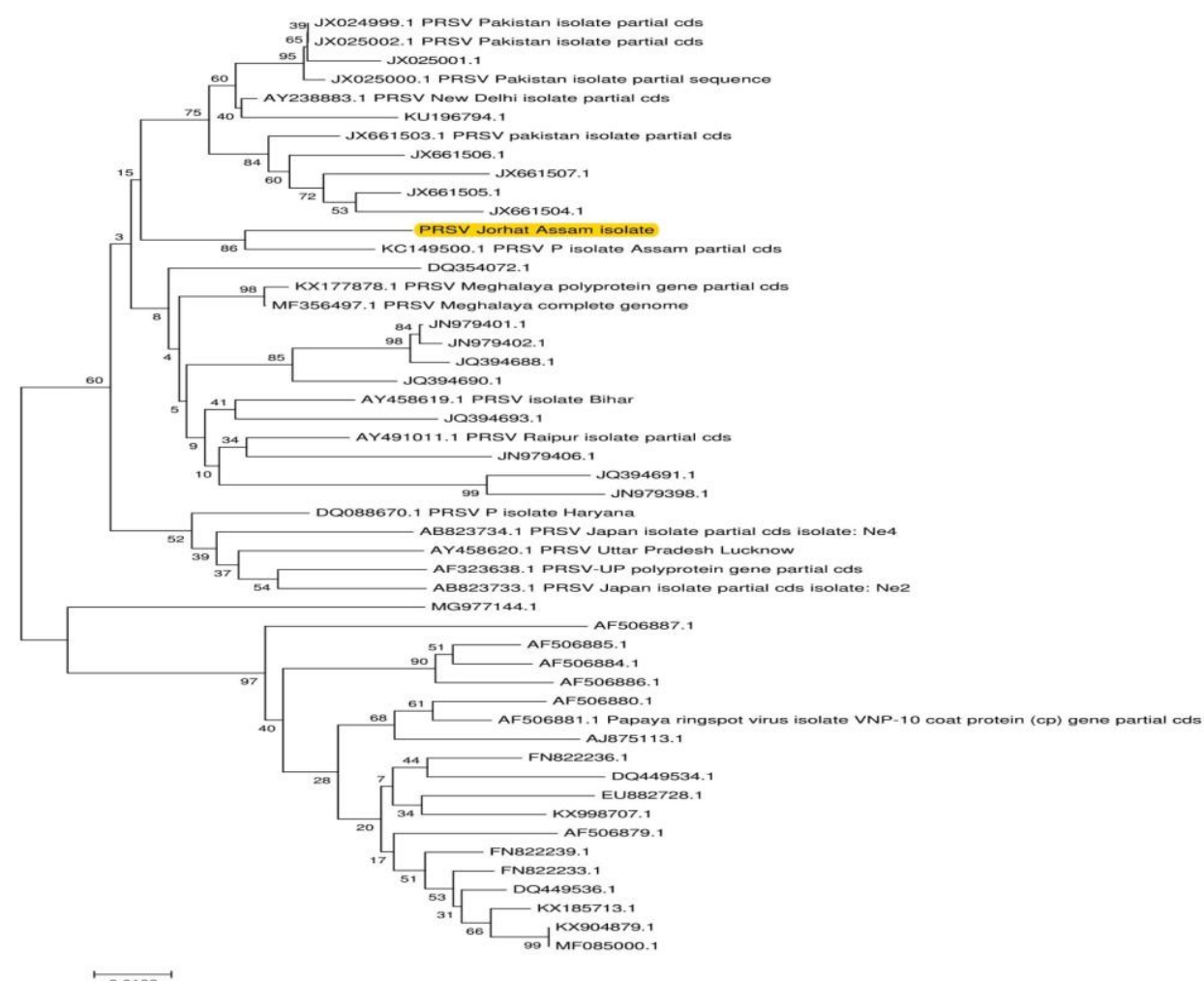


Bootstrapped neighbour joining method using the software MEGA 7 was used to create the phylogenetic tree. Phylogenetic analysis reveals that our isolate (PRSV Jorhat) is closely related to PSRV $\mathrm{P}$ isolate Assam Accession no. KC149500 (Fig. 3).

From the tree it is clear that there is higher sequence divergence within the PRSV population. It might be due to wide range of cropping systems and cultivation practices followed in different geographical regions of Indian subcontinent. Therefore diversity might have occurred in different levels of selection pressure on PRSV (Pushpa et al., 2018).

In conclusion, the Papaya ring spot virus (PRSV) disease exhibited different types of symptoms on papaya plants but the diagnosis of PRSV based on symptoms is confusing because of varied climatic conditions or due to the effect of deficiency of micronutrient in soil. Therefore in future studies developing rapid and sensitive assays such as RT-PCR, ELISA, LAMP, DIBA, Immuno capture and tissue imprint is very crucial for molecular diagnosis of PRSV. The insights from the Coat Protein gene characterization studies of Jorhat isolate would contribute to the understanding of the PRSV genome variability across the world as well as India which is valued information towards designing the region specific transgenic papaya lines.

\section{References}

Akad, F. and H. Czosnek, (2002). Virus Detection: Potato Virus Y(PVY) and PVY $^{\mathrm{N}}$, Method: RT-PCR. The Hebrew University, Technical Sheet No.1.

Davis, M.J. and Ying, Z. 1999. Genetic diversity of the Papaya ringspot virus in Florida. Proc. Fla. State. Hort. Soc. 112: 194-196.
Ferwerda Licha, M. (2002). Mixed infection of papaya ringspot virus, zucchini yellow mosaic virus and papaya bunchy top affecting papaya (Carica papaya L) in Puerto Rico. Phytopathology. 92(6): S25. Garzón-Tiznado, J.A., Acosta-García, G. Torres-Pacheco, I., González-Chavira, M., Rivera-Bustamante, R.F., MayaHernández, V. and Guevara-González, R.G. (2002). Presencia de los geminivirus, huasteco del chile (PHV), texano del chile variante Tamaulipas (TPV-T), y chino del tomate (VCdT), en los estados de Guanajuato, Jalisco y San Luis Potosí, México. Revista Mexicana de Fitopatología. 20(1): 45-52.

Hwang, J.S. and Hsieh, F.K. (1984). Studies on aphid transmission of papaya ringspot virus. Plant Prot. Bull. Taiwan. 26: 395400.

Jain R.K., Sharma J and Verma A. (2004) Present status of Papaya ring spot virus population profile in India. Annu Rev Plant Pathol 3: 1-15.

Jensen, D.D. (1949). Papaya virus diseases with special reference to papaya ringspot. Phytopathology. 39: 191-211.

Karkashian, J.P., Maxwell, D.P. and Ramirez, P. 2002. Squash yellow mottle geminivirus: a new cucurbit-infecting geminivirus from Costa Rica. Phytopathology. 92: S125.

Kawano, S. and Yonoha, T. 1992. The occurrence of papaya leaf distortion mosaic virus in Okinawa. Tech. Bull. Food. Fert. Technol. Center. 132: 12-23.

Khurana S.M.P., Bhargava K.S. (1970) Induced apocarpy and "double papaya" fruit formation in papaya with Distortion ringspot virus infection. Plant Disease Reptr., 54(2): 181-183.

Mali, V.R. (1985). Important potyviruses occurring on crop plants and others hosts in India. Int. J. Trop. Plant Dis. 3: 93115.

Marys E.E., Carballo O., Izaguirre Maycoral 
M.L. (2000) Occurrence and relative incidence of virus infected papaya in Venezuela. Ann Appl Biol 136(2): 121124.

McLean, D.M. and Olson, E.O. (1962). Symptoms of tobacco ringspot on papaya. Plant Dis. Rep. 46: 882.

Purcifull, D.E. and Hiebert, E. (1971). Papaya mosaic virus. CMI/AAB Descriptions of Plant Viruses. 56. pp4.

Purcifull, D.E., Edwardson, J.R., Hiebert, E. and Gonsalves, D. (1984). Papaya ringspot virus. CMI/AAB Descriptions of Plant Viruses, 292(84): pp8.

Purcifull, D.E., Edwardson, J.R., Hiebert, E. and Gonsalves, D. (1984). Papaya ringspot virus. CMI/AAB Descriptions of plant viruses. 292(84): 8.

Pushpa R.N., Shantamma, Anil Pappachan, Manjunath B., Bhose Sumit, Sawan Kumar, Rangaswamy K.T., Girish T.R. and Nagaraju N. (2018) Molecular characterization, epidemiology and management of the papaya ringspot virus (prsv) in papaya under southern Indian conditions. International Journal of Agriculture Sciences pp.-5029-5038.

Rezende, J.A.M. and Costa, A.S. (1986). Reaction of papaya varieties to 13 potyviruses. Phytopathology. 12: 187194.

Rezende, J.A.M. and Costa, A.S. (1987). Four viruses infecting papaya plants experimentally. Fitopatol. Bras. 12: 6365.

Rezende, J.A.M. and Costa, A.S. (1987). Four viruses infecting papaya plants experimentally. Fitopatol. Bras. 12: 6365.
Saxena, S., Hallan, V., Singh, B.P. and Sane, P.V. 1998. Nucleotide sequence and intergeminiviral homologies of the DNAA of papaya leaf curl geminivirus from India. Biochem. Mol. Biol. Int. 45(1): 101-13.

Singh S.J. (2003) Virus and phytoplasma disease of papaya, passion fruit and pineapple. Kalyani Publishers Ludhiana pp. 147.

Surekha S.K., Mathur K., Shukla D.D. (1978) Virus diseases of papaya (Carica papaya L.) in Udaipur Indian. J Mycol Pl Pathol 7: 115-121.

Verma A.K. (1996) Viral and mycoplasmal diseases of papaya (Carica papaya $\mathrm{L}$ ). Disease scenario in crop plants. Vol. 1Fruits and Vegetables (eds) Agnihotri VP, Om Prakash, Ram Kishun, Mishra A. International Books and Periodical Supply Service, India, pp. 156- 175.

Verma H.N., Prasad V (1986) Virus diseases in papaw (papaya) Rev Trop Pl Path 9: 311-327.

Wang, C. H. and Yeh S. D. (1997). Divergence and conservation of the genomic RNAs of Taiwan and Hawaii strains of papaya ring spot potyvirus. Archives of Virology 142: 271 - 285.

Wang, H.L. (1981). Aphid transmission of papaya ringspot virus in Taiwan. Plant Prot.Bull. Taiwan. 23: 229-233.

Yeh, S. D. and Gonsalves, D.(1985). Translation of Papaya ringspot virus RNA. In vitro detection of a possible polyprotein that is processed for capsid protein, cylindrical inclusion protein and amorphous inclusion protein. Virology, 143: 260-271.

\section{How to cite this article:}

Shankar Hemanta Gogoi, P.D. Nath, N. Thakuria, S. Gogoi, B. Das, N. Deka and Raj, K. 2019. Molecular Detection and Characterization of Papaya Ring Spot Virus (PRSV) Disease in Jorhat District of Assam, India. Int.J.Curr.Microbiol.App.Sci. 8(02): 1564-1571. doi: https://doi.org/10.20546/ijcmas.2019.802.183 